\title{
Dr Thomas A. Perfetti, Recipient of the 2017 Tobacco Science Research Conference Lifetime Achievement Award
}

\author{
Laudatio to the award given by \\ Carr J. Smith, Ph.D., DABT \\ Toxicology Advisor, Albemarle Corporation, Adjunct Teaching Faculty, \\ Florida State University Department of Nurse Anesthesia, FL, USA
}

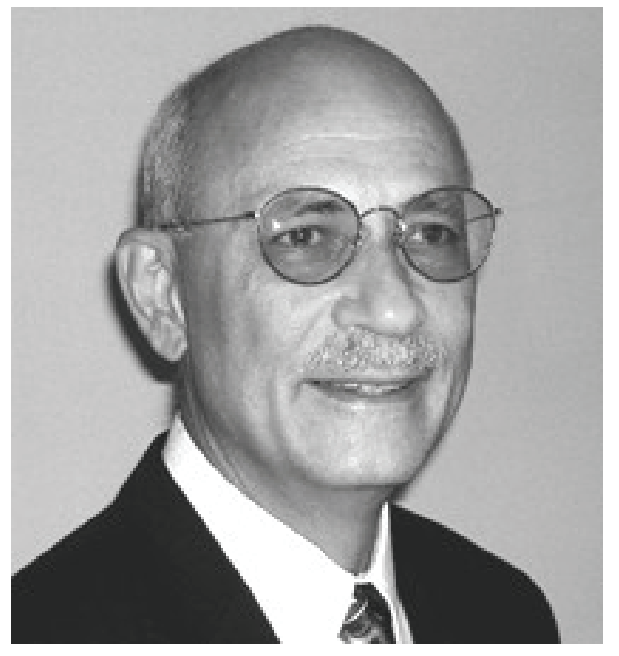

It is a privilege to introduce Thomas Albert Perfetti as the $15^{\text {th }}$ recipient of the Lifetime Achievement Award of the Tobacco Science Research Conference. Tobacco science is a critically important area of scientific endeavor given tobacco's historical role, economic impact, international ubiquity, and relevance to public health. Through this award, the TSRC has done a tremendous job of recognizing outstanding scientists that have contributed much to our understanding of the agronomy, processing, and production of tobacco, formation and composition of tobacco smoke, analytical chemistry, and the biological implications of tobacco and tobacco smoke chemistry. Tobacco science has profited greatly from partnerships among its outstanding scientists. When one thinks of tobacco science research teams, Alan Rodgman and Tom Perfetti quickly come to mind. It is fitting that Tom Perfetti now joins Alan Rodgman as a recipient of the TSRC Lifetime Achievement Award.
Tom Perfetti is an extremely hard worker, and is descended from a line of extremely hard workers. In 1913, Tom's grandfather Alberto (Albert) Perfetti left tiny Scerne in the Abruzzi region of Italy on the Adriatic Sea coast. Alberto (Albert) Perfetti arrived at the port of entry in Galveston, Texas on November 2. Alberto Perfetti had an inside and outside trade - master shoemaker and carpenter. As a teenager, Alberto was apprenticed to a master shoemaker, although the concept of a teenager wasn't recognized during that time period. Tom's great-grandmother paid the master shoemaker for this training. During the several years prior to Alberto mastering the craft of shoemaking, the master shoemaker punished his pupils by biting them on the head for insufficient performance. So, Tom, please keep that in mind when you say that my data tables are excessively long. If Alberto is looking down on us now, I think he would be very proud of his grandson.

Thomas Albert Perfetti was born to Ruth Peters and Bruno Massimo Perfetti in Jeannette, Pennsylvania in 1952. Like his grandfather Albert he was the second son. Tom had four siblings. He received his elementary school education in the Pittsburgh area, and entered Indiana University of Pennsylvania (IUP) in 1970. Already interested in conducting scientific research, Tom conducted cell transport research with Dr Richard Hartline and also synthesized numerous radiopharmaceuticals. This research led to the publication of the first of his 49 peer-reviewed publications.

With his interest in research stoked by his early success as an undergraduate, Tom entered Virginia Polytechnic Institute and State University (VPI-SU) in 1974. Under Professor Michael Ogliaruso, Tom wrote his doctoral thesis on the electronic effects associated with the Woodward-Hoffmann Rules. While in pursuit of his Ph.D. in physical organic chemistry, Tom was a Research Fellow for NASA, taught organic chemistry lab, and tutored undergraduate students. During this period, he won the VPI-SU President's Award for Distinguished Teaching. 
Forty-two years ago, Tom entered into by far his most important and successful collaboration when he married Patricia Ann Finley, whom he met in the Chemistry Department at IUP in 1973 and married in 1975. Pat and Tom have two sons, Michael and David, and the family resides in Winston-Salem, NC. Tobacco science runs in the family as Pat is an accomplished tobacco research scientist in her own right.

The Perfetti family is replete with chemists. Tom's father Bruno and Uncle Guido are polymer/coatings chemists. His uncle Rudy was an electro-chemist. Older brother Randolph and ex-wife Gracia are bio-organic and surface science chemists, respectively. Sister Barbara is a polymer chemist. So, it makes sense that Tom married Patricia who is also a chemist. In addition, Tom and Pat's son Michael is drug chemist. So the tradition continues.

In late 1977, Tom began a long and productive career in the Research Department of R.J. Reynolds Tobacco Company (RJRT). Starting as a research chemist, he initiated a diverse series of research programs on a variety of topics including tobacco chemistry, cigarette design, sensory science, flavor chemistry, process engineering, and analytical method development. In recognition of the success and productivity of these programs, Tom was promoted to Senior Research Chemist in 1979, Senior Staff Scientist in 1984, Master Scientist in 1986, and five years later to Principal Scientist.

Many of us first became aware of Tom Perfetti's work through his efforts in the areas of nicotine and menthol chemistry, and innovation. In addition to his contributions as a researcher, in his role as a Principal Scientist, Tom also worked with R.J. Reynolds-Nabisco and R.J. Reynolds International on corporate program development and program management issues. Among the many hats Tom wore at RJR were those of patent acquisition and patent application liaison, and consultant on scientific aspects of litigation. Although much of his career was spent at the laboratory bench, Tom also served as the manager of several divisions.

In addition to his contributions at RJR, Tom served as a reviewer for Tobacco Science, the Journal of Food and Chemical Toxicology, and Beiträge zur Tabakforschung International. He served on several Tobacco Chemists' Research Conference committees and contributed to two of its symposia in 1987 and 1993, chairing the 1993 symposium.

Tom is a long-time member of the American Chemical Society, and has contributed to ACS in a variety of capacities. He has served as assistant historian to the Division of the History of Chemistry. He is a member and Fellow of the American Institute of Chemists and is a Certified Professional Chemist. Tom was a co-founder and pastpresident of the North Carolina Chromatography Discussion Group and former chairman of the Education Commit- tee of the Central North Carolina Section of the ACS.

Over the last 40 years Tom has made over 60 scientific presentations, and his aforementioned 49 published peerreviewed papers span the areas of biochemistry, tobacco and smoke chemistry, sensory perception, mathematics, toxicology, and innovation. During his career at RJR, he prepared more than 250 formal company research reports. He has authored or co-authored three book chapters, and developed and presented five courses in the areas of cigarette design and innovation. Tom holds 45 US Patents and hundreds of foreign patents. In 2008, he co-authored with Dr Alan Rodgman the book The Chemical Components of Tobacco and Tobacco Smoke. In 2013, a Second Edition of their book was published.

Tom's accomplishment-laden career has garnered a variety of forms of recognition including citation in Who's Who in America, Who's Who in Science and Technology, in the International Directory of Distinguished Leadership and Who's Who in American Leaders in America. In 1993, he was presented with the Distinguished Alumni Award, Indiana University of Pennsylvania. In 1995, Tom and several other RJRT scientists received the George Land World-Class Innovator Award for outstanding work in instilling the principles of innovation at RJRT Research and Development. Rodgman and Perfetti won the 2010 CORESTA Prize for their classic The Chemical Components of Tobacco and Tobacco Smoke.

After retiring from RJRT in 2003, Tom and Pat founded the Winston-Salem based scientific consulting firm Perfetti \& Perfetti, LLC. The firm serves the flavoring and tobacco industries and specializes in national (FDA) and international regulatory and compliance issues associated with tobacco and tobacco products, and new-generation smoking articles and consults with companies concerned with plant extraction processes, bio-processing and bio-refining of plant materials into useful chemicals. Not surprisingly, this enterprise has done quite well garnering national and international clients. Tom also continues to pursue active research with a current emphasis on better understanding how in vitro assays of mutagenicity and in vivo rodent bioassays of carcinogenicity are affected by different chemicals and chemical classes. It has been a tremendous amount of fun to work with such a good scientist and an even better person.

\author{
Carr J. Smith, Ph.D., DABT \\ Toxicology Advisor \\ Albemarle Corporation \\ Adjunct Teaching Faculty \\ Florida State University Department of Nurse Anesthesia \\ E-mail:Carr.Smith@albemarle.com
}

